\title{
Growth, biomass, leaf area and water-use efficiency of juvenile Pinus radiata in response to water deficits
}

Matthew J Waghorn ${ }^{1 *}$, David Whitehead ${ }^{2}$, Michael S Watt ${ }^{3}$, Euan G Mason ${ }^{1}$ and Jonathan J Harrington ${ }^{3}$

\begin{abstract}
Background: As the frequency and severity of drought events are expected to increase globally, drought-induced reductions in plantation productivity are likely to become more important. Such reductions will be of concern to forest managers looking to improve forest productivity during the establishment and initial growth phases of plantation-grown Pinus radiata D. Don. The objective of this research was to assess how growth, biomass, leaf area and water-use efficiency in juvenile Pinus radiata responded to the timing and duration of water deficits.
\end{abstract}

Methods: Two-year-old Pinus radiata seedlings (cultivated in a polyhouse) were subjected to various water deficit treatments. Needle water potential, tree growth, biomass partitioning, leaf characteristics and water-use efficiency were measured to assess the impact that the timing and duration of water deficits had on productivity.

Results: Cyclical re-watering of the early- and late-season drought treatments led to large fluctuations in needle water potential. The summer drought treatment resulted in a sustained low needle water potential over the summer months. Total water stress integral $\left(S_{\psi}\right)$ was 41.4, 66.8, 55.2 and 97.6 MPa-days for the well-watered, early-season cyclical drought, late-season cyclical drought and summer drought treatments, respectively. In general, water deficits decreased tree growth, reduced crown size, reduced biomass accumulation and leaf area, and resulted in more enriched values of $\delta^{13} \mathrm{C}$, all of which were significantly $(P<0.05)$ affected by treatment. Summer drought reduced height, diameter and basal area by $24.7 \%, 33.1 \%$ and $52.3 \%$, respectively. Total biomass was reduced by $64.7 \%$ and total leaf area by $40.0 \%$, compared with the well-watered treatment. The reduction in stem diameter growth was larger for the late-season treatment than the early-season treatment when compared with the well-watered trees suggesting that late-season drought is more detrimental than early-season drought to tree growth.

Conclusion: The results provide insight for forest managers of Pinus radiata into the importance of managing water deficits in order to maximise forest production of juvenile trees. Results suggest that late-season drought is more detrimental to absolute growth and biomass accumulation than early-season drought.

Keywords: Biomass; Clone; Growth; Leaf area; Pinus radiata; Productivity; Water deficits; Water stress; Water-use efficiency

\section{Background}

Pinus radiata $\mathrm{D}$. Don productivity is an important issue for forest managers in New Zealand. Increased or indeed diminished growth of $P$. radiata is directly related to a site's ability to provide resources to a forest crop. One of the major factors potentially limiting forest production is water availability (Linder 1987; Johnson 1990; Gower

\footnotetext{
* Correspondence: mjwaghorn@hotmail.com

${ }^{1}$ School of Forestry, University of Canterbury, Private Bag 4800, Christchurch, New Zealand

Full list of author information is available at the end of the article
}

et al. 1992) and this is of particular importance for juvenile conifer growth (Sands and Nambiar 1984). Water deficits or drought can greatly influence the amount of foliage produced by a stand and consequently have a direct effect upon the fractional interceptance of radiation (Benson et al. 1992) and thus, net carbon gain and the potential growth rate of the stand.

During drier periods, reductions in available soil water result in closure of stomata, which in turn constrains growth of $P$. radiata and other conifers. While this response to water deficits helps conserve water by

\section{勿}


limiting evaporative losses, it also reduces carbon dioxide uptake, thereby reducing photosynthetic rate, tree growth and wood production (Waring and Franklin 1979; Benecke 1980; Whitehead 1985; Thompson and Wheeler 1992; Yunusa et al. 1995a). Many plant traits are related to water uptake including hydraulic conductance, resistance to embolism, leaf to root ratios and root distribution (Hacke et al. 2000; Pinol and Sala 2000; Martinez-Vilalta et al. 2004). Earlier work by Rook et al. (1977) showed that greater levels of water stress caused transpiration and photosynthesis to decline to near zero, which induced shedding of older foliage.

With such pronounced physiological responses to water deficits in $P$. radiata, variation in morphology is expected. In response to water deficits, Rook et al. (1977) found that diameter and root growth were among the first processes to be affected. As a generalisation, morphological features such as diameter, height, basal area and leaf area are detrimentally impacted by water deficits (Jackson et al. 1976; Bongarten and Teskey 1987; Linder et al. 1987; Johnson 1990; Albaugh et al. 1998), which is of concern to forest managers looking to optimise forest growth.

Water deficits may also influence juvenile conifer productivity by altering partitioning of biomass between above- and below-ground tree components. Previous studies of $P$. radiata subjected to varying degrees of water availability have clearly shown that decreased availability of water reduces above-ground biomass accumulation (Snowdon and Benson, 1992; Woods et al. 1992; Yunusa et al. 1995a; Watt et al. 2003; Espinoza et al. 2013). However, the partitioning of biomass to aboveground components is often contradictory between studies (Snowdon and Benson, 1992; Watt et al. 2003).

Tree water stress can be interpreted from the ratio of the two stable carbon isotopes ${ }^{12} \mathrm{C}$ and ${ }^{13} \mathrm{C}$ found in plant material, known as $\delta^{13} \mathrm{C}$. The $\delta^{13} \mathrm{C}$ ratio is the result of discrimination against the heavier ${ }^{13} \mathrm{CO}_{2}$ during diffusion through the stomata and consequent carboxylation in favour of the lighter ${ }^{12} \mathrm{CO}_{2}$ (Farquhar et al. 1989; Brienen et al. 2011). Discrimination is linearly related to the ratio of leaf intercellular $\mathrm{CO}_{2}$ concentration $\left(C_{\mathrm{i}}\right)$ to atmospheric $\mathrm{CO}_{2}$ concentration $\left(C_{\mathrm{a}}\right)$ (i.e. $\left.C_{\mathrm{i}} / C_{\mathrm{a}}\right)$, which reflects the balance between the rate of inward $\mathrm{CO}_{2}$ diffusion, mediated by stomatal conductance, and the rate of $\mathrm{CO}_{2}$ assimilation in photosynthesis (Warren et al. 2001). Hence, drought stress related decreases in stomatal conductance and relative $\mathrm{CO}_{2}$ concentration in the leaf are often correlated with increases (less negative values) in $\delta^{13} \mathrm{C}$ of newly formed photosynthates (Farquhar et al. 1989). Water-use efficiency (the ratio of assimilation to transpiration) is also related to $C_{\mathrm{i}} / C_{\mathrm{a}}$, thus the $\delta^{13} \mathrm{C}$ ratio and water-use efficiency are positively related. The $\delta^{13} \mathrm{C}$ signature of tree material is widely regarded as a reliable proxy for water-use efficiency (Kruse et al. 2012).

Past research has shown that forest managers can influence soil water availability through choices in site, stand density and level of weed control (Nambiar 1990; Stogsdili et al. 1992; Yunusa et al. 1995b; Watt et al. 2003; Watt et al. 2006). Furthermore, it has been shown that growth of $P$. radiata is very sensitive to water stress during the juvenile phase (Sands and Nambiar 1984). In addition to the impact of forest management practices on water availability, global climate change is increasingly affecting seasonal rainfall distribution (Basher 2000; Kenny 2001). Therefore possible changes in water availability due to changes in weather with increasingly erratic seasonal rainfall and more frequent and severe drought events, coupled with increased evaporative demand brought about by higher temperatures have the potential to alter forest growth and reduce primary production (Kirschbaum and Fischlin 1996). At present, soil water deficits are common across many eastern regions of New Zealand during summer (Palmer et al. 2009) and many of these areas are predicted to receive less rainfall in the future (Mullen et al. 2005; Kirschbaum et al. 2012).

It is important for forest managers to be able to understand the response of growth and canopy dynamics of juvenile $P$. radiata to water deficits. In general, forest managers and researchers have a suitable understanding of the impacts of extended summer drought on accumulative growth and general productivity of juvenile trees (e.g. Snowdon and Waring 1991). However, this knowledge does not extend to the consequences of early-season (spring) or late-season (autumn) drought. Given that morphological and physiological processes can be different between spring and autumn and that different types of wood are being formed (earlywood vs. latewood), it is necessary to examine how either early- or late-season droughts compare with extended summer drought and well-watered conditions. As such, the early- and late-season drought results were of primary interest in this study.

The primary objective of this study was to assess how key growth characteristics in juvenile $P$. radiata respond to the timing and duration of water deficits over the course of one growing season. Specifically, this study sought to: (i) examine the effect that the timing and duration of water deficits has on productivity; (ii) quantify how early- and late-season water deficits influences above-ground biomass accumulation; and (iii) investigate water-use efficiency in response to the timing and duration of water deficits.

\section{Methods}

\section{Experimental design and treatments}

The experiment was undertaken in a polyhouse using $P$. radiata clonal stock. The nursery-raised trees were 
planted in the polyhouse for a two-year period with experimental treatments applied during the second year. The clone used was a high wood density, high acoustic velocity clone (Clone 35, Forest Genetics CellFor Ltd) produced using somatic embryogenesis. The trees were planted in a free-draining loamy sand soil within 200 litre pots to reduce any potential for water logging and root binding.

Soil particle size was determined using a hydrometer for smaller particles and sieve for larger particles prior to the experiment. Particles were separated into $<0.002$, $0.0021-0.06,0.061-0.2,0.21-0.6$ and $0.61-2.0 \mathrm{~mm}$ size fractions. A comprehensive set of soil chemical measurements were made (Table 1). Six bulked soil samples were analysed for $\mathrm{pH}$ in water, total carbon $(\mathrm{C})$, total nitrogen $(\mathrm{N})$, Olsen phosphorus $(\mathrm{P})$, exchangeable bases and cation exchange capacity (CEC), following the methods described by Blakemore et al. (1987).

The clonal tree material grown in the polyhouse was subjected to four water deficit treatments laid out in six blocks of five rows for one growing season (start of August 2009 to end of August 2010). Within each block of five rows, all four water deficit treatments were present plus one buffer row. Each treatment, which occupied one row, consisted of four trees. The treatments within each block were randomly assigned. The buffer row within each block was placed systematically on the next row to the north of rows subject to the summer drought treatment so that shading of the drought trees

Table 1 Mean soil physical and chemical properties

\begin{tabular}{ll}
\hline Variable & Value \\
\hline Soil physical properties (\%) & 59 \\
Coarse sand & 17 \\
Medium sand & 8 \\
Fine sand & 8 \\
Silt & 8 \\
Clay & \\
Soil chemical properties & 6.2 \\
Total C $(\%)$ & 0.26 \\
Total N (\%) & 23.9 \\
C:N ratio & 6.4 \\
pH & 22 \\
CEC (cmol/kg) & 0.53 \\
Exchangeable $\mathrm{Na}(\mathrm{cmol} / \mathrm{kg})$ & 1.68 \\
Exchangeable K (cmol/kg) & 2.77 \\
Exchangeable Mg (cmol/kg) & 12.6 \\
Exchangeable Ca (cmol/kg) & 82 \\
Base saturation $(\%)$ & 69 \\
Olsen P (mg/kg) & \\
\hline
\end{tabular}

and thus any confounding influences were minimised. Trees were spaced $1.4 \mathrm{~m}$ apart so that there was no physical interaction between their crowns. Twenty four trees per treatment were used giving a total of 96 trees for the experiment.

Four water deficit treatments were applied to the experimental trees. Irrigation was applied using drip sprinklers until soil moisture capacity was reached. The first treatment was 'well-watered' with applications of water applied weekly between October and May (spring to autumn), and fortnightly between June and September (winter). The second treatment simulated 'extended summer drought' whereby water was withheld between November and April to allow drying of the soil profile. The drought was interrupted by the small, single application of water on March 1 to prevent tree mortality. Although predawn needle water potentials were not particularly low at this time, the trees had started showing large physical changes to continued drought. During the remainder of the year, water was applied at the same times as the well-watered treatment. The third and fourth treatments simulated 'early-season cyclical drought' and 'late-season cyclical drought', respectively. The earlyseason cyclical drought treatment was applied between October and January (spring/early summer), while the late-season cyclical drought treatment was applied between February and May (late summer/autumn). These treatments were timed to coincide with periods of expected early- and latewood development. Trees in these treatments were subjected to a series of drying cycles interrupted by water replenishment when needle water potential had fallen to approximately $-0.5 \mathrm{MPa}$ or lower. The early-season drought trees were re-watered on November 7, December 1, December 26 and January 16, while the late-season drought trees were re-watered on February 20, March 13 and April 19. This water potential was sufficient to generate a depressed growth response as previously observed in non-experimental trees. When not subject to the cyclical watering treatments between the stated months, water for both treatments was applied at the same times as that for the well-watered treatment. The length of time between watering for the cyclical drought treatments depended upon the time of year and air temperature. The time between watering varied from three to seven weeks during the October to May period. These cycles were expected to create large fluctuations in needle water potential.

\section{Climatic variables}

Climatic variables within the polyhouse were measured throughout the duration of the experiment. Variables measured daily were air temperature, relative humidity and daytime photosynethically active irradiance (PAR). These variables were measured using sensors connected 
to a data logger (HOBO weather station, ONSET Computer Corporation, Bourne, MA, USA). Vapour pressure deficit $(D)$ was calculated from measurements of air temperature and relative humidity (Allen et al. 1998).

\section{Measurements of tree growth}

Measurements relating to tree growth were taken during year two. Monthly measurements of total tree height and diameter (at a tree height of $0.5 \mathrm{~m}$ ) were made. Ground-line diameter was also measured every second month. Both measures of diameter were made on a single axis for all trees using a pair of electronic callipers. Whole tree litterfall from both current and second-year needles was collected monthly, dried at $70^{\circ} \mathrm{C}$ until constant weight was achieved and aggregated over the year for each treatment.

\section{Predawn needle water potential}

Measurements of predawn needle water potential $\left(\psi_{\mathrm{e}}\right)$ were made throughout the experiment using a pressure chamber. Three trees per treatment were sampled on each occasion. The timing of sampling depended on the season with weekly sampling occurring during spring, summer and autumn and fortnightly sampling occurring during winter. From each tree, three fascicles were collected from the youngest, well developed foliage. The fascicles were collected before dawn and stored in test tubes on ice until $\psi_{\mathrm{e}}$ was measured, which was always within one hour of collection. Following Myers (1988), water stress integral $\left(S_{\psi}\right)$ was determined as the cumulative integral of predawn needle water potential over the period which water deficits were imposed (1 October to 31 May). In addition to total values of $S_{\psi}$, monthly $S_{\psi}$ was also calculated. Values of $S_{\psi}$ are expressed as an absolute sum, so that larger values of $S_{\psi}$ represent greater accumulated water deficits.

Measurements of final tree growth, biomass and leaf area At the conclusion of the experiment at the end of August 2010, prior to destructive sampling, final measurements of tree height, diameter at $0.5 \mathrm{~m}$ up the stem and ground-line diameter were made for all trees. Stem slenderness was calculated as the ratio of tree height to ground-line diameter. Basal area was calculated using Husch et al. (2003). Crown dimensions were measured for all trees. The number of whorls, internode length, number of branches per whorl, branch diameter and branch length were measured. The largest branch diameter in each quadrant of the whorl was measured and branch diameter was defined as the mean of the largest branch in each of the four quadrants.

Total above-ground and component biomasses were determined by destructively harvesting 48 trees at the end of the experiment (12 trees per treatment). Trees were separated into stem, branch and foliage components. All biomass components were dried to $70^{\circ} \mathrm{C}$ until constant mass was achieved, then weighed.

Leaf area was measured for 24 randomly selected trees (six per treatment) at the conclusion of the experiment. Leaf area by year was obtained by removing all foliage and separating into year-one and year-two growth based on measurements of height. Although treatments were only imposed during year two, year-one leaf area was assessed in order to examine subsequent retention of drought affected leaves. Following Beets (1977), specific leaf area was determined from measurements of fascicle diameter, length, and dry mass based on a subsample of 20 fascicles from both year-one and year-two age classes. Values for leaf area are presented on the basis of half the total surface area. The number of fascicles per tree was estimated as total tree foliage dry weight divided by leaf area fascicle subsample dry weight.

\section{Foliar $\delta^{13} \mathrm{C}$ isotope composition}

Foliage stable carbon isotope ratios $\left(\delta^{13} \mathrm{C}\right)$ were measured for six trees per treatment (24 trees total) at the conclusion of the experiment. Oven-dried foliage samples from the year-two foliage of each sampled tree were ground in a Wiley mill to $<200 \mu \mathrm{m}$. Using $3 \mathrm{mg}$ of ground sample material, carbon isotope composition was determined using a Dumas Elemental Analyser (Europa Scientific ANCA-SL) interfaced to a Stable Isotope Mass Spectrometer (Europa Scientific Tracermass, Europa Scientific Ltd, Crewe, UK). The ${ }^{13} \mathrm{C} /{ }^{12} \mathrm{C}$ ratios are expressed as delta $(\delta)$ values in thousandths $(\%)$. All analyses were run against the CSIRO sucrose standard $\left(\delta^{13} \mathrm{C}=-10.8 \%\right.$ ) and sample $\delta^{13} \mathrm{C}$ was calculated relative to the Pee Dee Belemnite standard. The standard deviation of repeated $\delta^{13} \mathrm{C}$ measurements of the laboratory samples was $0.3 \%$. The carbon isotope composition was calculated from:

$$
\delta^{13} \mathrm{C}(\%)=\left(R_{\text {sample }} / R_{\text {standard }}-1\right) \times 1000
$$

where $R$ represents the ratio of ${ }^{13} \mathrm{C} /{ }^{12} \mathrm{C}$ of samples and standards, respectively (Brienen et al. 2011).

\section{Statistical analysis}

All analyses were carried out using $\mathrm{R}$ software ( $\mathrm{R}$ Core Team 2013). Prior to the commencement of the experiment at the start of year two, measures of growth were made and analysed to ensure no location bias existed within the polyhouse. There were no statistically significant treatment differences in any of the measured variables at the start of the experiment. The effect of water deficits on tested variables were examined using a mixed-effects model that included treatment as a fixed effect, with block as a random effect. A repeated-measures 
ANOVA was used for measures of diameter, height and needle water potential. Tukey's HSD test was used, where applicable, to distinguish between treatment mean values. Differences were considered significant at $P<0.05$.

\section{Results \\ Climate}

Air temperature fluctuated between -1 and $35^{\circ} \mathrm{C}$ with a mean and standard deviation of $14.3 \pm 5.9^{\circ} \mathrm{C}$. Vapour pressure deficit fluctuated between 0.01 and $3.89 \mathrm{kPa}$ with a mean and standard deviation of $0.41 \pm 0.53 \mathrm{kPa}$. The maximum value of daytime photosynthetically active irradiance was $1023 \mu \mathrm{mol} \mathrm{m}{ }^{-2} \mathrm{~s}^{-1}$ while the minimum was $1.3 \mu \mathrm{mol} \mathrm{m}{ }^{-2} \mathrm{~s}^{-1}$. Annual variation in (a) average daily air temperature, (b) average daily vapour pressure deficit, and (c) average daytime photosynthetically active irradiance (PAR) are shown in Figure 1.

\section{Predawn needle water potential}

The implementation of the early-season drought, lateseason drought and summer drought treatments had a pronounced effect on $\psi_{\mathrm{e}}$ and induced consistently more negative values of $\psi_{\mathrm{e}}$ than for the well-watered trees (Figure 2). The early-season and late-season drought treatments resulted in large fluctuations of $\psi_{\mathrm{e}}$. The lowest value of $\psi_{\mathrm{e}}$ achieved for the early- and late-season drought treatments occurred during the first dryingrewetting cycle. Compared with these treatments, the summer drought treatment induced consistently more negative values of $\psi_{\mathrm{e}}$ during the period between midDecember and April. Values of total $S_{\psi}$ were 41.4, 66.8, 55.2 and $97.6 \mathrm{MPa}$-days for the well-watered, earlyseason drought, late-season drought and summer drought treatments, respectively.

\section{Tree characteristics}

Tree height plus both measures of diameter and basal area were all significantly influenced by treatment $(P<0.001)$. Stem slenderness was also significantly influenced by treatment $(P=0.012)$, but only due to the variation in slenderness between the wellwatered and early-season drought treatments. Basal area was the most sensitive indicator of water deficits as well-watered trees had double the basal area of the summer-drought trees (Table 2). With the imposition of water deficits, marked divergence in monthly diameter and height growth become immediately apparent (Figure 3). Decreased growth for all water deficit treatments coincided with more negative predawn needle water potential values. Diameter growth for the summer-drought treatment virtually ceased in March (0.04 $\mathrm{mm}$ growth for the month). However, the wellwatered and early-season drought treatments experienced their period of greatest incremental diameter

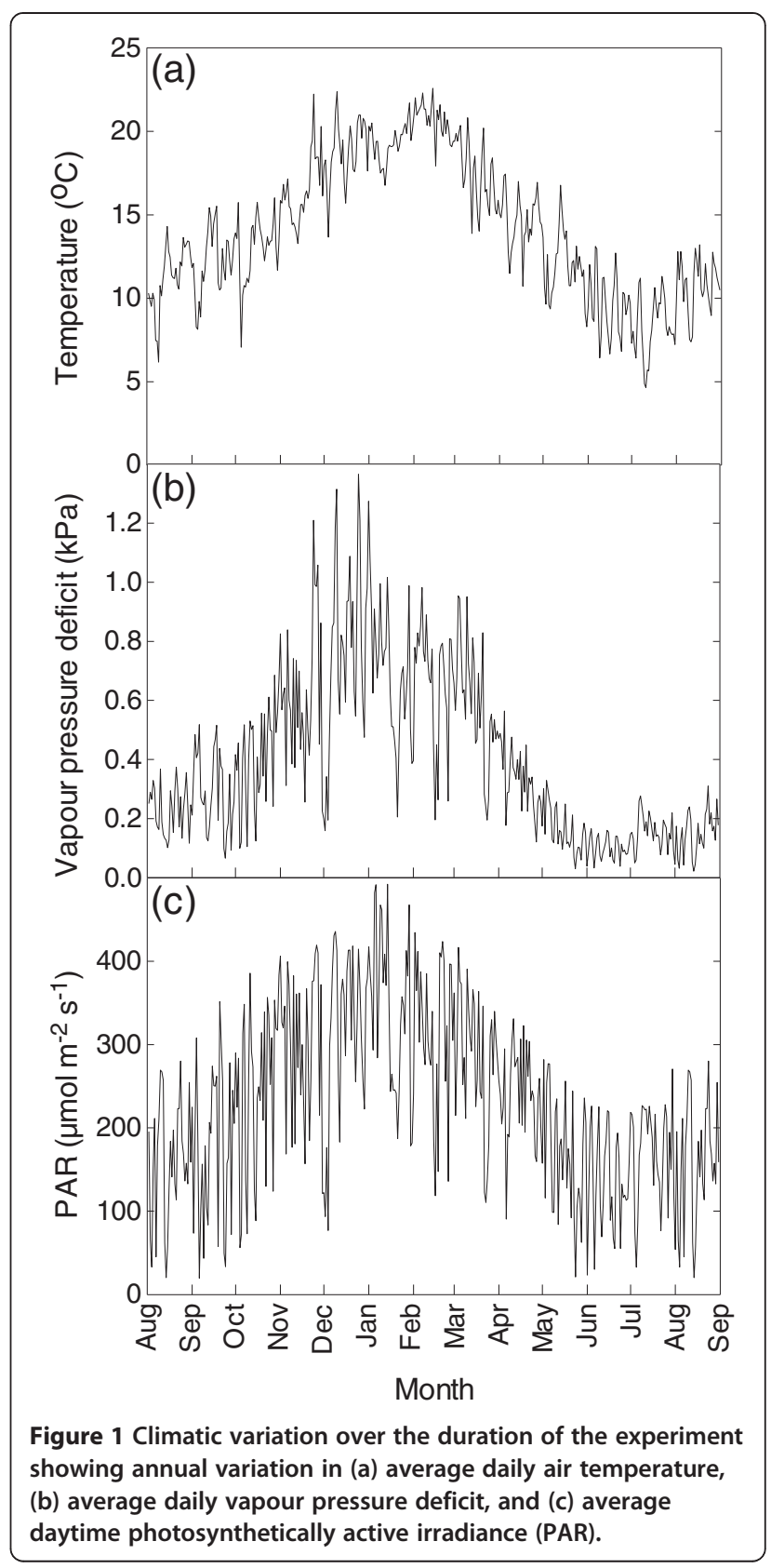

growth (3.16 and $3.36 \mathrm{~mm}$, respectively) during the same month. After exceedingly different growth trajectories during the preceding months, diameter growth had converged for all treatments by mid-winter (July). Height growth started increasing towards the end of the experiment in July even though this month had the lowest daily temperatures. Rapid increases in height growth occurred the following month. Diameter growth started increasing in August. Compared with the well-watered treatment, the summer drought treatment reduced height, diameter and basal area by $24.7 \%, 33.1 \%$ and $52.3 \%$, respectively. 


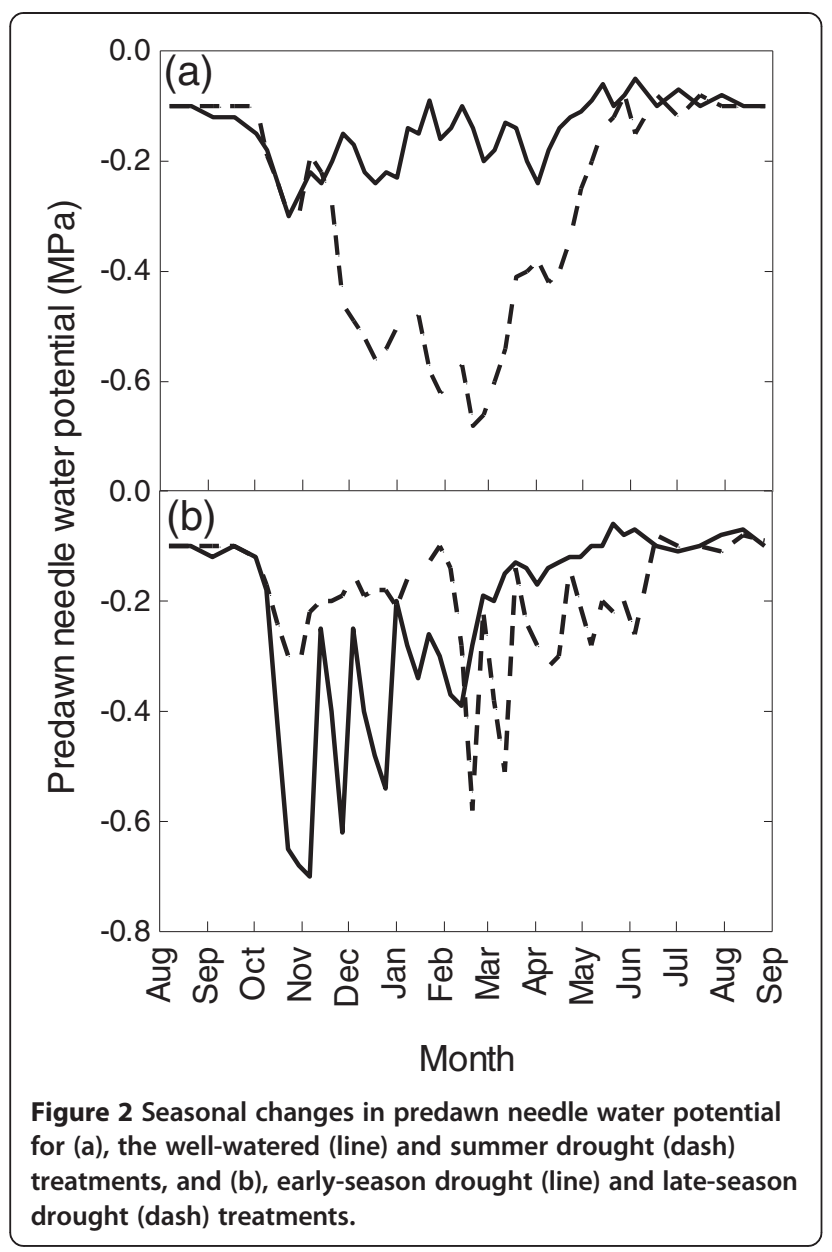

There were no significant differences $(P>0.05)$ in height, diameter and basal area between early- and lateseason drought trees at the end of the experiment (Table 2), although total $S_{\psi}$ was larger in the early season drought trees than in the late season drought trees. Monthly diameter growth was greater in early-season drought treatment trees even though they were subjected to higher levels of water stress than those in the late-season drought treatment. The relationship between monthly $S_{\psi}$ and diameter growth is illustrated in
Figure 4. Diameter growth was similar for both treatments irrespective of season during those periods when not subjected to water deficits and when monthly $S_{\psi}$ values were comparable.

Trees exposed to early-season drought between October and January increased in diameter by $5.36 \mathrm{~mm}$ during that period compared with $10.60 \mathrm{~mm}$ for the late-season drought trees and $10.17 \mathrm{~mm}$ for the well-watered trees. When water deficits were imposed between February and May for the late-season drought trees, their diameter increased by $2.37 \mathrm{~mm}$ compared with $8.90 \mathrm{~mm}$ for the early-season drought and $9.41 \mathrm{~mm}$ for the well-watered treatment trees. The reduction in stem diameter growth was higher for the late-season treatment than the earlyseason treatment when compared with the well-watered trees (Figure 3). Furthermore, the early-season drought trees recovered rapidly after water stress, and even surpassed the well-watered trees for monthly stem height growth. This suggests that late-season drought is more detrimental than early-season drought to absolute tree growth.

The primary effect of water deficits on crown characteristics were reductions in branch diameter and branch length $(P<0.001)$. The magnitude of these effects increased with the severity of the water deficit treatment with branch length varying by two-fold between the well-watered and summer drought treatments (Table 3). The principal difference between the early- and lateseason drought treatments was the number of fascicles per tree, otherwise crown variables were similar. Although summer drought produced a very similar number of whorls and branches per whorl as the other treatments, branch diameter and length were considerably different. This suggests that summer drought does not significantly inhibit formation of lateral branching but the size they grow to.

Needle litterfall was significantly $(P<0.01)$ affected by treatment. The impact of cyclical drought on the earlyseason treatment ceased early enough to minimise needle loss, however, the late-season treatment showed significant needle loss, especially during the last three

Table 2 Treatment variation in tree dimensions at the end of the experiment

\begin{tabular}{llllll}
\hline Treatment & Tree height $(\mathbf{m m})$ & Diameter $(\mathbf{m m})$ & Ground-line diameter $(\mathbf{m m})$ & Basal area $\left(\mathbf{m m}^{\mathbf{2}}\right)$ & Slenderness \\
\hline Well-watered & $3544(55) \mathrm{a}$ & $38.3(0.8) \mathrm{a}$ & $44.8(1.0) \mathrm{a}$ & $1590(76) \mathrm{a}$ & $79.6(1.2) \mathrm{a}$ \\
Early-season drought & $3220(53) \mathrm{b}$ & $32.4(0.6) \mathrm{b}$ & $37.1(0.6) \mathrm{b}$ & $1086(35) \mathrm{b}$ & $87.0(1.0) \mathrm{b}$ \\
Late-season drought & $2997(59) \mathrm{b}$ & $30.6(0.6) \mathrm{b}$ & $35.8(0.6) \mathrm{b}$ & $1015(38) \mathrm{b}$ & $83.8(1.3) \mathrm{ab}$ \\
Summer drought & $2606(42) \mathrm{c}$ & $25.6(0.4) \mathrm{C}$ & $31.0(0.4) \mathrm{c}$ & $759(21) \mathrm{C}$ & $84.1(1.2) \mathrm{ab}$ \\
Analysis of variance & & & & $34.3^{* * *}$ & \\
Treatment & $37.3^{* * *}$ & $44.3^{* * *}$ & $45.3^{* * *}$ & $5.12^{*}$ \\
\hline
\end{tabular}

Each value is the treatment mean with standard error in parentheses for 24 trees. The Tukey HSD test was performed between treatments. Means followed by the same letter are not significantly different at $P<0.05$. Significance of treatment effects is shown as $F$ value followed by $P$ category: ${ }^{*}$ significant at $P<0.05$; ***significant at $P<0.001$. 

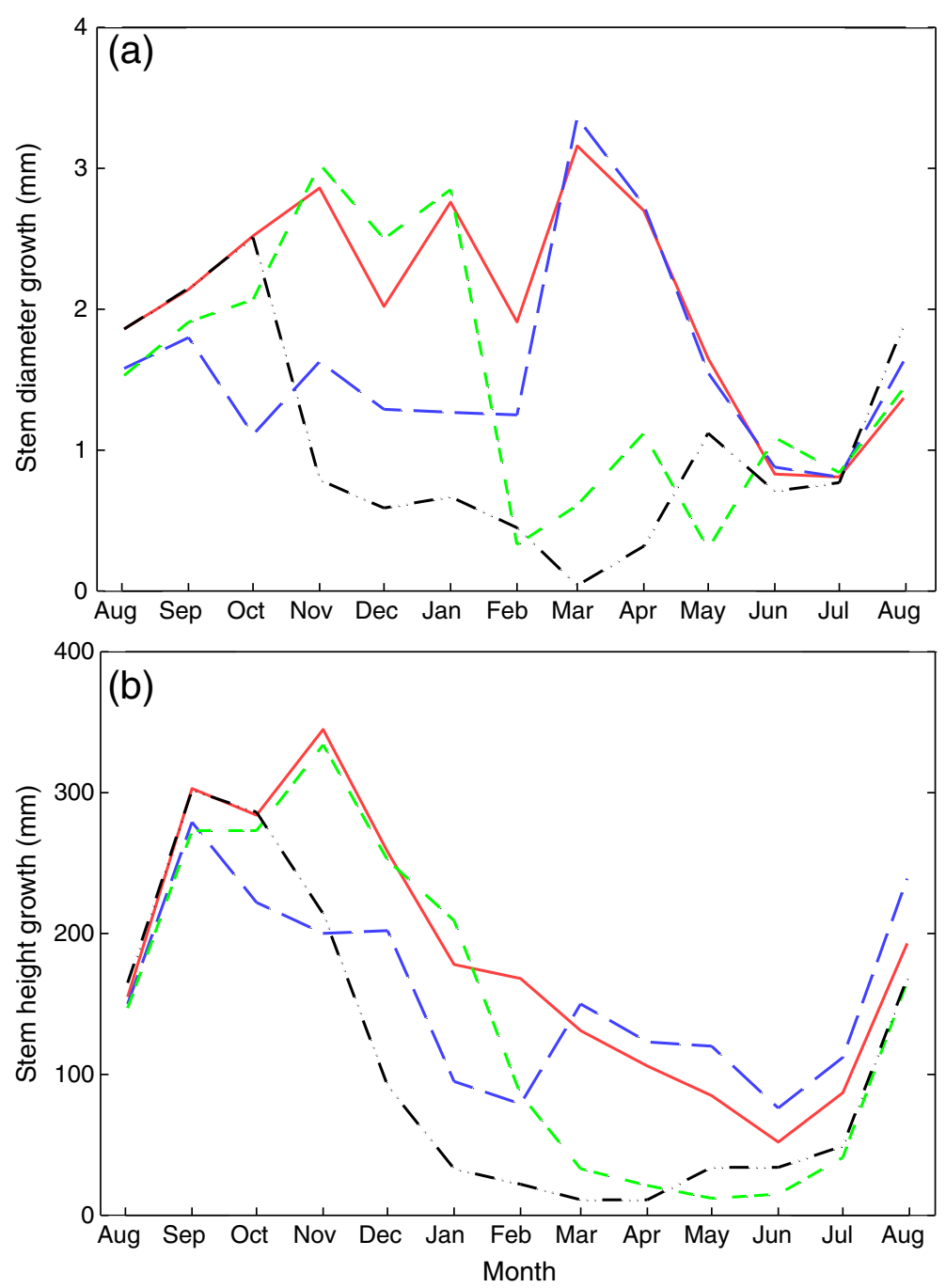

Figure 3 Average monthly incremental stem diameter growth (a) and height growth (b) for the well-watered (solid red line), early-season drought (long blue dash), late-season drought (short green dash) and summer drought (black dash-dot-dot) treatments.

months of the growing season when 5.18 grams of the total 6.88 grams fell. The large amount of litterfall from well-watered trees was most likely the result of tree size rather than a water deficit response.

\section{Biomass}

As expected, above-ground biomass component weights were influenced by treatment $(P<0.001)$. Stem and foliage biomasses of the early-season and late-season drought treatments were not significantly different $(P>0.05)$, (Table 4$)$. The difference in biomass between the well-watered and summer drought treatments was significant for all components but was most apparent for branch biomass which differed by a factor of just over 4 , compared with 3.5 for stem and 2.6 for foliage. Total biomass for the early-season, late-season and summer drought treatments was reduced by $36.3 \%, 44.8 \%$ and
68.3\% compared with the well-watered treatment. The relationship between woody biomass and foliage biomass was highly correlated $\left(r^{2}=0.91\right)$, indicating a strong functional relationship between conducting tissue of the tree and foliage.

\section{Leaf characteristics}

Leaf area varied considerably among treatments. A significant treatment effect was observed for year-one leaf $(P<0.001)$, year-two leaf $(P<0.01)$ and total leaf area $(P<0.0001)$. Although water deficits were only imposed during the second year, the effect on both the growth and development of the year-two foliage and the continued growth and retention of the year-one foliage was pronounced (Figure 5). The leaf area of year-two foliage for the well-watered treatment was double that of the summer drought treatment. The year-one, year-two 


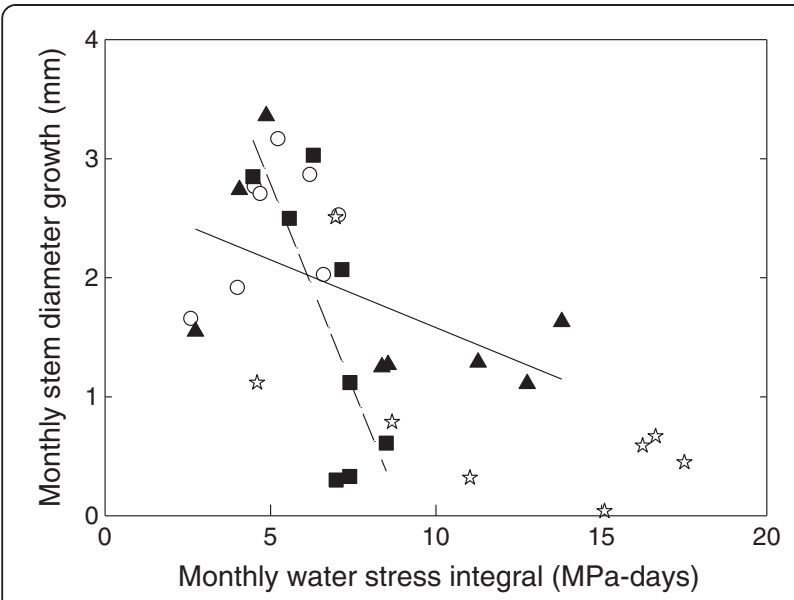

Figure 4 The relationship between monthly water stress integral $\left(S_{\psi}\right)$ and monthly stem diameter growth for the period between October 2009 and May 2010 for the well-watered (open circles), early-season drought (filled triangle), late-season drought (filled square) and summer drought (open star) treatments. Best fit lines have been included for the early-season drought (solid line, $r^{2}=0.33$ ) and late-season drought (dashed line, $\left.r^{2}=0.57\right)$ treatments. The slopes were significantly different $(P=0.0356)$.

and total leaf areas were not significantly different between the early-season and late-season drought treatments $(P>0.05)$. Values of total leaf area of the earlyseason, late-season and summer drought treatments were $71 \%, 73 \%$ and $60 \%$, respectively, of that for the well-watered treatment.

\section{Estimates of water-use efficiency}

Significant treatment differences in $\delta^{13} \mathrm{C}(P=0.0375)$ were observed. The well-watered trees showed significantly lower $\delta^{13} \mathrm{C}$ values over the entire growth period compared with those for the summer drought trees because of higher soil water availability. The summer drought treatment had the most enriched values of $\delta^{13} \mathrm{C}$, with an average of $-25.93 \%$ compared to $-26.57 \%$, $-26.65 \%$ and $-27.20 \%$ for the lateseason, early-season and well-watered treatments, respectively. The variability among treatments (1.27\%o) was smaller than the variation within the early-season drought treatment (3.06\%). Across all samples, foliar $\delta^{13} \mathrm{C}$ ranged from $-25.29 \%$ o to $-28.63 \%$ (range of $3.14 \%$ ).

\section{Discussion}

Previous experiments on dry sites that included irrigation have shown that water deficits limit tree growth by regulating the period during which tree growth is possible (Benson et al. 1992). Growth of trees in the wellwatered treatment was largely unaffected by water stress as confirmed from measurements of predawn needle water potential, which did not fall below -0.30 MPa. Although differences among treatments in predawn needle water potentials were often quite small, Myers (1988) showed that small differences maintained over long periods can lead to large changes in growth. Improved water availability led to increased growth, and distinct differences were observed between the well-watered, cyclical drought and summer drought treatments in the current study.

The higher slope for the late-season drought treatment in Figure 4 means that similar monthly water stress integral had a more pronounced effect on monthly stem diameter growth compared with the early-season drought treatment, whilst demonstrating that the earlyseason drought trees experienced greater levels of water stress (total $S_{\psi}=66.8$ vs. $55.2 \mathrm{MPa}$-days). In addition, the early-season drought trees rapidly recovered from water stress and exceeded the well-watered treatment for monthly stem height growth, whilst the late-season drought trees remained suppressed through to the end of the experiment and into the new growing season. This result demonstrates the complex interactions between the phenology of foliage production, partitioning of photosynthates and the availability of resources during different seasons. Although the early- and late-season

Table 3 Crown characteristics at the end of the experiment

\begin{tabular}{llllll}
\hline & Well-watered & Early-season drought & Late-season drought & Summer drought & Analysis of variance treatment \\
\hline No. of whorls & $2.3(0.1) \mathrm{a}$ & $2.3(0.1) \mathrm{a}$ & $2.3(0.1) \mathrm{a}$ & $2.2(0.1) \mathrm{a}$ & $0.49^{\mathrm{ns}}$ \\
Internode length $(\mathrm{cm})$ & $61.8(3.1) \mathrm{a}$ & $58.3(3.1) \mathrm{ab}$ & $60.0(2.2) \mathrm{ab}$ & $50.6(3.0) \mathrm{b}$ & $3.29^{\mathrm{ns}}$ \\
Branches per whorl & $7.6(0.2) \mathrm{ab}$ & $6.8(0.2) \mathrm{a}$ & $7.6(0.2) \mathrm{ab}$ & $7.7(0.2) \mathrm{b}$ & $3.89^{*}$ \\
Branch diameter (cm) & $7.8(0.2) \mathrm{a}$ & $6.3(0.2) \mathrm{b}$ & $6.4(0.2) \mathrm{b}$ & $4.9(0.1) \mathrm{c}$ & $45.8^{* * *}$ \\
Branch length (cm) & $40.3(1.9) \mathrm{a}$ & $29.2(1.3) \mathrm{b}$ & $31.3(1.7) \mathrm{b}$ & $20.8(1.3) \mathrm{c}$ & $44.2^{* * *}$ \\
Needle length (cm) & $12.9(0.4) \mathrm{a}$ & $12.1(0.2) \mathrm{a}$ & $12.1(0.5) \mathrm{a}$ & $10.3(0.3) \mathrm{b}$ & $10.6^{* * *}$ \\
Fascicles per tree & $2643(404) \mathrm{a}$ & $2297(167) \mathrm{a}$ & $1704(123) \mathrm{a}$ & $1547(290) \mathrm{b}$ & $3.61^{*}$ \\
Litterfall (grams) & $5.0(0.7) \mathrm{ab}$ & $1.9(0.3) \mathrm{b}$ & $6.9(1.1) \mathrm{a}$ & $7.1(1.3) \mathrm{a}$ & $9.31^{* *}$
\end{tabular}

Each value is the treatment mean with standard error in parentheses for 24 trees, except for needle length which is for 6 trees. The Tukey HSD test was performed between treatments. Means followed by the same letter are not significantly different at $P<0.05$. Significance of treatment effects is shown as $F$ value followed by $P$ category: ${ }^{\mathrm{ns}}$ non-significant; ${ }^{*}$ significant at $P<0.05$; ${ }^{* *}$ significant at $P<0.01$; ${ }^{* * *}$ significant at $P<0.001$. 
Table 4 Above-ground biomass by treatment

\begin{tabular}{|c|c|c|c|c|}
\hline \multirow[b]{2}{*}{ Treatment } & \multicolumn{4}{|c|}{ Tree component biomass (g tree ${ }^{-1}$ ) } \\
\hline & Stem & Branches & Foliage & Total \\
\hline Well-watered & $350.1(31.8) a$ & 104.9 (12.9) a & $291.4(27.0) \mathrm{a}$ & $746.4(67.8) \mathrm{a}$ \\
\hline Early-season drought & $212.8(14.5) b$ & $56.7(5.0) \mathrm{b}$ & $206.5(10.0) b$ & $475.9(27.1) b$ \\
\hline Late-season drought & $187.1(9.0) b$ & $55.3(4.8) b$ & $169.9(10.0) b$ & $412.3(20.5) b$ \\
\hline Summer drought & $100.2(8.5) \mathrm{c}$ & $25.2(3.3) \mathrm{c}$ & $111.6(9.8) \mathrm{C}$ & $236.9(19.9) \mathrm{C}$ \\
\hline \multicolumn{5}{|l|}{ Analysis of variance } \\
\hline Treatment & $36.4^{* * *}$ & $49.5^{* * *}$ & $52.9^{* * *}$ & $51.4^{* * *}$ \\
\hline
\end{tabular}

drought treatments were implemented at different times of the year when different factors may have been influencing tree growth, such as air temperature and vapour pressure deficit, comparisons with the well-watered trees as the control treatment allow for direct comparisons between the relative effects of early- and late-season drought on physical measures of tree growth.

Diameter growth rates of the well-watered trees remained high until late autumn. However, there was a decline in incremental diameter growth for the summer months of December and February, which was possibly caused by atmospheric conditions. The highest values of vapour pressure deficit occurred in early summer (December) and the highest daily average temperatures in late summer (February). When the vapour pressure deficit increases, stomatal conductance decreases (Beneke 1980), thus reducing photosynthesis. It has also been shown that cell diameters decrease in the radial direction when the temperature is above $15^{\circ} \mathrm{C}$ (Jenkins 1975). These reductions in rate of diameter growth, more so for December than February, coincide

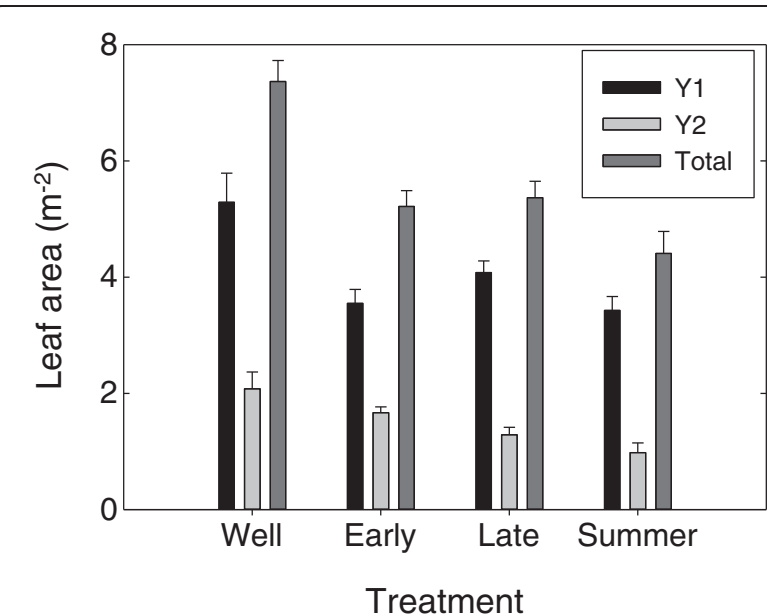

Figure $\mathbf{5}$ Leaf area for year one, year two and total tree foliage for the well-watered, early-season drought, late-season drought and summer drought treatments. with the main period of needle elongation. The foliage would thus have been a strong competing sink for assimilates, reducing the amount of resources available for diameter growth (Linder et al. 1987). The high vapour pressure deficit also affected the late-season drought treatment in December resulting in reduced diameter growth.

Distinct differences in biomass were observed among the well-watered, cyclical drought and the summer drought treatments. The well-watered trees in this study had over three-fold the total biomass of the summer drought trees and a four-fold difference in branch biomass which exceeded the difference for any other tree components between these treatments. This was driven by large differences in branch diameter and length. As the water stress integral increased, above-ground biomass was preferentially allocated to stem and branches over foliage. The strong positive relationship between woody biomass and foliage biomass across all treatments and tree sizes in this experiment conforms to the pipe model theory advocated by Shinozaki et al. (1964a, b). These results suggest that, in juvenile $P$. radiata, estimates of canopy leaf area can be made from the sapwood area at the base of the tree.

Water deficits resulted in smaller needles, reduced leaf area and considerably smaller crowns. Smaller crowns were the result of reduced branch length and diameter, and reduced number of fascicles. Pronounced differences existed for year-one, year-two and total leaf area across all treatments. Water deficits would have impacted on the growth and retention of year one foliage as well as the formation and growth of the year-two foliage. Earlyseason drought was expected to retard continued formation and growth of needles during the latter part of the growing season, however, this did not occur. It has been shown that needles on later season flushes can continue to develop until all above-ground growth sinks are halted and at the same rate as those earlier in the growing season (Rook et al. 1987; Dougherty et al. 1994).

The magnitude of $\delta^{13} \mathrm{C}$ in plant foliage is determined by both stomatal conductance and photosynthetic capacity (Farquhar et al. 1989) so photosynthetic activity 
throughout the period the leaf tissue was synthesised impacts on $\delta^{13} \mathrm{C}$ (McNulty and Swank 1995; Barbour et al. 2002; Dawson et al. 2002). In response to water deficits, stomatal conductance decreases to prevent excessive water losses, leading to reduced values for $C_{\mathrm{i}}$ and lower ${ }^{13} \mathrm{C}$ discrimination (Farquhar and Sharkey 1982). Since stomatal conductance is proportional to water loss (given similar ambient conditions), $\delta^{13} \mathrm{C}$ is positively correlated with water-use efficiency (Farquhar and Richards 1984). Thus, given that the summer drought treatment had the most enriched values of $\delta^{13} \mathrm{C}$, the results imply that the summer drought treatment had the greatest water-use efficiency and, as such, fixed the most carbon per unit amount of water transpired. Under water stress, diameter and height growth, above-ground biomass, and foliage area were significantly decreased, while water-use efficiency was significantly increased.

\section{Conclusion}

Strong positive correlations between water availability and various aspects of growth of juvenile $P$. radiata were observed in this experiment. Implementation of water deficit treatments resulted in pronounced reductions in tree dimensions, above-ground biomass accumulation, leaf area and increases in water-use efficiency compared with the well-watered treatment. Treatment effects were significant for all variables tested $(P<0.05)$. At a similar monthly water stress integral, late-season drought trees experienced a greater reduction in monthly stem diameter growth compared with the early-season drought trees, suggesting that late-season drought is more detrimental to tree growth and biomass accumulation in juvenile $P$. radiata than early-season drought. The results herein clearly demonstrate the benefit to forest managers of improved water availability to juvenile $P$. radiata to ensure sound establishment and vigorous growth and can be useful for improving both silvicultural and environmental approaches to forest management.

\section{Competing interests}

The authors declare that they have no competing interests.

\section{Authors' contributions}

MJW was the primary author and undertook the majority of analyses. DW assisted with some analyses, interpretation of data and experimental conception and design. MSW and EGM helped draft the manuscript and along with $\mathrm{JJH}$ assisted with experimental conception and design. All authors read and approved the final manuscript.

\section{Acknowledgements}

The lead author is grateful to Timberlands Ltd for in-kind support and providing the clonal tree stock. The lead author was supported by the University of Canterbury Doctoral Scholarship and funding from Scion.

\section{Author details}

${ }^{1}$ School of Forestry, University of Canterbury, Private Bag 4800, Christchurch, New Zealand. ${ }^{2}$ Landcare Research, PO Box 40, Lincoln, New Zealand. ${ }^{3}$ Scion, PO Box 29237, Fendalton, Christchurch, New Zealand.
Received: 20 May 2014 Accepted: 9 March 2015

Published online: 17 April 2015

\section{References}

Albaugh, TJ, Allen, HL, Dougherty, PM, Kress, LW, \& King, JS. (1998). Leaf area and above- and belowground growth responses of loblolly pine to nutrient and water additions. Forest Science, 44, 317-328.

Allen, RG, Pereira, LS, Raes, D, \& Smith, M. (1998). Crop Evaporation - Guidelines for Computing Crop Water Requirements. FAO Irrigation and Drainage Paper 56. Chapter 3 - Meteorological Data. Rome: Food and Agriculture Organization.

Barbour, MM, Walcroft, AS, \& Farquhar, GD. (2002). Seasonal variation in $\delta^{18} \mathrm{C}$ and $\delta^{13} \mathrm{C}$ of cellulose from growth rings of Pinus radiata. Plant, Cell and Environment, 25, 1483-1499.

Basher, RE. (2000). The Impacts of Climate Change on New Zealand. In A Gillespie \& WCG Burns (Eds.), Climate Change in the South Pacific: Impacts and Responses in Australia, New Zealand and Small Island States (pp. 121-142). Dordrecht, Netherlands: Kluwer Academic Publishers.

Beets, P. (1977). Determination of the fascicle surface area for Pinus radiata. New Zealand Journal of Forestry Science, 7, 397-407.

Benecke, U. (1980). Photosynthesis and transpiration of Pinus radiata D. Don under natural conditions in a forest stand. Oecologia, 44, 192-198.

Benson, ML, Myers, BJ, \& Raison, RJ. (1992). Dynamics of stem growth of Pinus radiata as affected by water and nitrogen supply. Forest Ecology and Management, 52, 117-137.

Blackmore, LC, Searle, PL, \& Daly, BK. (1987). Methods for Chemical Analysis of Soils. New Zealand Soil Bureau Scientific Report No. 80. Wellington, New Zealand: Department of Scientific and Industrial Research.

Bongarten, BC, \& Teskey, RO. (1987). Dry weight partitioning and its relationship to productivity in loblolly pine seedlings from seven sources. Forest Science, 33, 255-267.

Brienen, RJW, Wanek, W, \& Hietz, P. (2011). Stable carbon isotopes in tree rings indicate improved water use efficiency and drought responses of a tropical dry forest tree species. Trees, 25, 103-113.

Dawson, TE, Mambelli, S, Plamboeck, AH, Templer, PH, \& Tu, KP. (2002). Stable isotopes in plant ecology. Annual Review of Ecology and Systematics, 33, 507-559.

Dougherty, PM, Whitehead, D, \& Vose, JM. (1994). Environmental influences on the phenology of pine. Ecological Bulletins, 43, 64-75.

Espinoza, SE, Magni, CR, Martinez, VA, \& Ivkovic, M. (2013). The effect of water availability on plastic responses and biomass allocation in early growth traits of Pinus radiata D. Don. Forest Systems, 22, 3-14.

Farquhar, GD, \& Sharkey, TD. (1982). Stomatal conductance and photosynthesis. Annual Review of Plant Physiology and Plant Molecular Biology, 33, 317-345.

Farquhar, GD, \& Richards, RA. (1984). Isotopic composition of plant carbon correlates with water use efficiency of wheat genotypes. Australian Journal of Plant Physiology, 11, 539-552.

Farquhar, GD, Ehleringer, JR, \& Hubick, KT. (1989). Carbon isotope discrimination and photosynthesis. Annual Review of Plant Physiology and Plant Molecular Biology, 40, 503-537.

Gower, ST, Vogt, KA, \& Grier, CC. (1992). Carbon dynamics of Rocky Mountain Douglas-fir: influence of water and nutrient availability. Ecological Monographs, 62, 43-65.

Hacke, UG, Sperry, JS, Ewers, BE, Ellsworth, DS, Schafer, KVR, \& Oren, R. (2000). Influence of soil porosity on water use in Pinus taeda. Oecologia, 124, 495-505.

Husch, B, Beers, TW, \& Kershaw, JA, Jr. (2003). Forest Mensuration (4th ed.). New Jersey, USA: John Wiley \& Sons, Inc.

Jackson, DS, Gifford, HH, \& Chittenden, J. (1976). Environmental variables influencing the increment of Pinus radiata: (2) Effects of seasonal drought on height and diameter increment. New Zealand Journal of Forestry Science, 5, 265-286

Jenkins, PA. (1975). Influence of temperature change on wood formation in Pinus radiata grown in controlled environments. New Zealand Journal of Botany, 13, 579-592.

Johnson, JD. (1990). Dry-matter partitioning in loblolly and slash pine: effects of fertilisation and irrigation. Forest Ecology and Management, 30, 147-157.

Kenny, G. (2001). Climate Change: Likely Impacts on New Zealand Agriculture. Wellington, New Zealand: Ministry for the Environment.

Kirschbaum, MUF, \& Fischlin, A. (1996). Climate Change Impact on Forests. In RT Watson, MC Zinyowera, \& RH Moss (Eds.), Climate Change 1995. Impacts, Adaptations and Mitigation of Climate Change: Scientific-Technical Analyses (pp. 95-130). Cambridge, UK: Cambridge University Press. 
Kirschbaum, MUF, Watt, MS, Tait, A, \& Ausseil, AE. (2012). Future wood productivity of Pinus radiata in New Zealand under predicted climatic changes. Global Change Biology, 18, 1342-1356.

Kruse, J, Hopmans, P, Rennenberg, P, \& Adams, M. (2012). Modern tools to tackle traditional concerns: Evaluation of site productivity and Pinus radiata management via $\delta^{13} \mathrm{C}$ - and $\delta^{18} \mathrm{O}$ - analysis of tree-rings. Forest Ecology and Management, 285, 227-238.

Linder, S. (1987). Responses to Water and Nutrients in Coniferous Ecosystems. In ED Schulze \& H Zwolfer (Eds.), Ecological Studies (Potentials and limitations of ecosystem analysis, Vol. 61, pp. 180-202). Berlin, Germany: Springer Berlin Heidelberg

Linder, S, Benson, ML, Myers, BJ, \& Raison, RJ. (1987). Canopy dynamics and growth of Pinus radiata. I. Effects of irrigation and fertilisation during a drought. Canadian Journal of Forest Research, 17, 1157-1165.

Martinez-Vilalta, J, Sala, A, \& Pinol, J. (2004). The hydraulic architecture of Pinaceae - a review. Plant Ecology, 171, 3-13.

McNulty, SG, \& Swank, WT. (1995). Wood $\delta^{13} \mathrm{C}$ as a measure of annual basal area growth and soil water stress in a Pinus strobus forest. Ecology, 76, 1581-1586.

Mullan, B, Porteous, A, Wratt, D, \& Hollis, M. (2005). Changes in Drought Risk With Climate Change. A Report Prepared for the Ministry for the Environment and Ministry of Agriculture and Forestry. Wellington, New Zealand: NIWA.

Myers, BJ. (1988). Water stress integral - a link between short term stress and long term growth. Tree Physiology, 4, 315-323.

Nambiar, EKS. (1990). Interplay between nutrients, water, root growth and productivity in young plantations. Forest Ecology and Management, 30, 213-232.

Palmer, DJ, Watt, MS, Hock, BK, Lowe, DJ, \& Payn, TW. (2009). A Dynamic Framework for Spatial Modelling Pinus Radiata Soil Water Balance (SWatBal) Across New Zealand. Forest Research Bulletin No. 234. Rotorua, New Zealand: Scion.

Pinol, J, \& Sala, A. (2000). Ecological implications of xylem cavitation for several Pinaceae in the Pacific Northern USA. Functional Ecology, 14, 538-545.

R Core Team. (2013). R: A language and environment for statistical computing R Foundation for Statistical Computing. http://www.R-project.org/.

Rook, DA, Swanson, RH, \& Cranswick, AM. (1977). Reaction of Radiata Pine to Drought. In Proceedings of Soil and Plant Water Symposium (pp. 55-68). Wellington, New Zealand: New Zealand Department of Scientific and Industrial Research Information Series No. 126. Department of Scientific and Industrial Research.

Rook, DA, Bollmann, MP, \& Hong, SO. (1987). Foliage development within the crowns of Pinus radiata trees at two spacings. New Zealand Journal of Forestry Science, 17, 297-314.

Sands, R, \& Nambiar, EKS. (1984). Water relations of Pinus radiata in competition with weeds. Canadian Journal of Forest Research, 14, 233-237.

Shinozaki, K, Yoda, K, Hozumi, K, \& Kira, T. (1964a). A quantitative analysis of plant form - the pipe model theory.l. Basic analyses. Japanese Journal of Ecology, 14, 97-105.

Shinozaki, K, Yoda, K, Hozumi, K, \& Kira, T. (1964b). A quantitative analysis of plant form - the pipe model theory. II. Further evidence of the theory and its application in forest ecology. Japanese Journal of Ecology, 14, 133-139.

Snowdon, P, \& Benson, ML. (1992). Effects of combinations of irrigation and fertilisation on the growth and above-ground biomass production of Pinus radiata. Forest Ecology and Management, 52, 87-116.

Snowdon, P, \& Waring, AM. (1991). Effect of irrigation and artificial drought on the growth and health of Pinus radiata near Canberra, A.C.T. Australian Forestry, 54, 174-186.

Stogsdili, WR, Wittwer, RF, Hennessey, TC, \& Dougherty, PM. (1992). Water use in thinned loblolly pine plantations. Forest Ecology and Management, 50, 233-245.

Thompson, WA, \& Wheeler, AM. (1992). Photosynthesis by mature needles of field grown Pinus radiata. Forest Ecology and Management, 52, 225-242.

Waring, RH, \& Franklin, JF. (1979). Evergreen coniferous forests of the Pacific Northwest. Science, 204, 1380-1386.

Warren, CR, McGrath, JF, \& Adams, MA. (2001). Water availability and carbon isotope discrimination in conifers. Oecologia, 127, 476-486.

Watt, MS, Whitehead, D, Mason, EG, Richardson, B, \& Kimberley, MO. (2003). The influence of weed competition for light and water on growth and dry matter partitioning of young Pinus radiata, at a dryland site. Forest Ecology and Management, 183, 363-376.
Watt, MS, Moore, JR, Facon, J, Downes, GM, Clinton, PW, Coker, G, Davis, MR Simcock, R, Parfitt, RL, Dando, J, Mason, EG, \& Bown, HE. (2006). Modelling the influence of stand structural, edaphic and climatic influences on juvenile Pinus radiata dynamic modulus of elasticity. Forest Ecology and Management, 229, 136-144

Whitehead, D. (1985). A Review of Processes in the Water Relations of Forests. In J Landsberg \& W Parsons (Eds.), Research for Forest Management (pp. 94-124). Canberra, Australia: CSIRO.

Woods, PV, Nambiar, EKS, \& Smethurst, PJ. (1992). Effect of annual weeds on water and nitrogen availability to Pinus radiata trees in a young plantation. Forest Ecology and Management, 48, 145-163.

Yunusa, IAM, Mead, DJ, Lucas, RJ, \& Pollock, KM. (1995a). Process studies in a Pinus radiata - pasture agroforestry system in a subhumid temperate environment. II. Analysis of dry matter yields in the third year. Agroforestry systems, 32, 185-204

Yunusa, IAM, Mead, DJ, Pollock, KM, \& Lucas, RJ. (1995b). Process studies in a Pinus radiata - pasture agroforestry system in a subhumid temperate environment. I. Water use and light interception in the third year. Agroforestry Systems, 32, 163-183.

\section{Submit your manuscript to a SpringerOpen ${ }^{\odot}$ journal and benefit from:}

- Convenient online submission

- Rigorous peer review

- Immediate publication on acceptance

- Open access: articles freely available online

- High visibility within the field

- Retaining the copyright to your article

Submit your next manuscript at $>$ springeropen.com 